ISSN. 2775-4324 (Online)

Journal of Physical Activity and Sports

Volume 2, Nomor 3, Desember 2021, 315-321

\title{
Pengembangan Alat Latihan Smash Dan Setter Bola Voli Di Taruna Merah Putih Semarang
}

\author{
Putra Raditia $^{1}$, Buyung Kusumawardhana ${ }^{2}$, Husnul Hadi ${ }^{3}$ \\ ${ }^{1}$ Universitas PGRI Semarang, J1. Gajah Raya No.40, Semarang, 50166, Indonesia \\ ${ }^{2}$ Universitas PGRI Semarang, J1. Gajah Raya No.40, Semarang, 50166, Indonesia \\ ${ }^{3}$ Universitas PGRI Semarang, J1. Gajah Raya No.40, Semarang, 50166, Indonesia \\ putraradit98@mail.com, Buyungkusumawardhana@upgris.ac.id. Husnulhadi@upgris.ac.id
}

\begin{abstract}
This study aims to develop a volleyball smash and setter training tool as a training aid that can provide effectiveness to both coaches and athletes. This research is research and development ( $\mathrm{R} \& \mathrm{~d})$. This research was carried out in several steps, namely: identification of potentials and problems, gathering information, product design, product manufacture, expert validation, product revision, testing, final product. The development of smash training tools and volleyball setters was previously validated by media experts, coaches, and 20 players for operational field trials. The subject of this research is the volleyball player Taruna Merah Putih Semarang. The data collection technique used in this study was using an instrument in the form of a questionnaire. The data analysis technique of this research is descriptive qualitative and percentage quantitative descriptive. The results showed that the volleyball smash and setter training tools were feasible to use as a volleyball sports training aid. These results were obtained from the validation results of a) media expert at $83.8 \%$ or feasible; b) trainer at $87.5 \%$ or feasible; c) players in operational field trials of $84.06 \%$ or feasible. Thus, the conclusion is that the smash and volleyball setter training tools have been declared fit for use as volleyball training aids.
\end{abstract}

Keywords: Exercise Tools, Smash and Setter, Volleyball.

\begin{abstract}
Abstrak
Penelitian ini bertujuan mengembangkan alat latihan smash dan setter bola voli sebagai alat bantu latihan yang dapat memberikan efektifitas kepada pelatih maupun atlet. Penelitian ini merupakan penelitian pengembangan atau research and development (R\&d). Penelitian ini dilakuhkan dengan beberapa langkah, yakni: identifikasi potensi dan masalah, pengumpulan informasi, desain produk, pembuatan produk, validasi ahli, revisi produk, uji coba, produk akhir. Pengembangan alat latihan smash dan setter bola voli terlebih dahulu divalidasi oleh ahli media, pelatih, dan 20 pemain utuk uji coba lapangan operasional. Subjek penelitian ini adalah pemain bola voli Taruna Merah Putih Semarang. Teknik pengumpulan data yang digunakan dalam penelitian ini dengan menggunakan instrumen berupa angket. Teknik analisis data penelitian ini adalah deskriptif kualitatif dan deskriptif kuantitatif persentase. Hasil penelitian menunjukan bahwa alat latihan smash dan setter bola voli adalah layak digunakan sebagai alat bantu latihan olahraga bola voli. Hasil tersebut diperoleh dari hasil validasi a) ahli media sebesar $83,8 \%$ atau layak; b) pelatih sebesar $87,5 \%$ atau layak; c) pemain uji coba lapangan oprasional sebesar $84,06 \%$ atau layak. Dengan demikian, kesimpulan bahwa alat latihan smash dan setter bola voli telah dinyatakan layak digunakan sebagai alat bantu latihan bola voli.
\end{abstract}

Kata Kunci : Alat Latihan, Smash dan Setter, Bola Voli. 


\section{PENDAHULUAN}

Olahraga merupakan suatu aktivitas gerak tubuh, mulai dari anggota tubuh bagian atas dan bagian bawah. Dikatakan aktivitas karena memiliki tujuan pada akhirnya, yakni kualitas hidup yang meningkat, sehingga manjadikan tubuh yang sehat dan bugar. Berdasarkan Undang-Undang No.3 tahun 2005 pasal 1 menyebutkan bahwa keolahragaan nasional adalah keolahragaan yang berdasarkan pancasila dan Undang-Undang Dasar Negara Republik Indonesia Tahun 1945 yang berakar pada nilai-nilai keolahragaan, kebudayaan nasional indonesia, dan tanggap terhadap tuntutan perkembangan olahraga. Aktivitas menyehatkan ini selain dijadikan aktivitas pengisi waktu luang, juga dapat di jadikan sebagai sarana untuk mengasah kemampuan diri dalam berolahraga atau wadah untuk menjadi atlet profesional atau prestasi. Olahraga prestasi adalah olahraga yang membina dan mengembangkan olahragawan secara terencana, berjenjang, dan berkelanjutan melalui kompetisi untuk mencapai dengan dukungan ilmu pengetahuan dan teknologi. Salah satu cabang olahraga yang cukup dikenal dalam lingkungan masyarakat atau yang lagi digemari berbagai kalangan yaitu bola voli, karena olahraga bola voli sangat digemari di berbagai kalangan usia.

Permainan bola voli merupakan salah satu cabang olahraga yang sering dimainkan oleh masyarakat Indonesia, permainan ini bisa dilakukan oleh semua kalangan masyarakat, mulai dari anak-anak sampai orang tua, laki-laki maupun perempuan, masyarakat desa maupun kota. Bukti bahwa olahraga ini sangat dicintai oleh pemain bola voli karena permainan ini cukup mudah untukdimainkan dan satu hal pasti yaitu menyehatkan. Atmasubrata (2012:50) mengatakan bola voli adalah olahraga permainan yang dimainkan oleh dua grup berlawanan, masing-masing grup memiliki enam orang pemain dan terdapat pula variasi permainan bola voli pantai yang masing-masing grup hanya memiliki dua orang pemain. Permainan bola voli sangat populer dan digemari oleh masyarakat mulai dari masyarakat pedesaan sampai perkotaan, baik pria maupun wanita dan juga mulai dari anakanak, remaja, dewasa sampai lansia.

Permainan bola voli sendiri merupakan olahraga yang sebenarnya dapat dinikmati dan dimainkan oleh beragam usia dan tingkat kemampuan, selain dapat di mainkan oleh pria atau wanita peralatan yang di butuhkan juga tidak terlalu sulit di dapatkan. Ahmadi, (2007:20) mengatakan bola voli merupakan suatu permainan yang kompleks yang tidak mudah dilakukan oleh setiap orang, sebab dalam permainan bola voli dibutuhkan koordinasi gerak yang benar-benar bisa diandalkan untuk melakukan semua gerakan yang ada dalam permainan bola voli" Bola voli merupakan permainan di atas lapangan persegi empat dengan lebar 9 meter dan panjang 18 meter, dibatasi oleh garis selebar 5 $\mathrm{cm}$. Di tengah-tengahnya di pasang jaring atau net yang panjangnya 9 meter atau selebar lapangan, terbentang kuat dengan ketingian 2,43 meter untuk laki-laki dan 2,24 untuk perempuan dari bawah.

Dalam permainan bola voli terdiri atas beberapa teknik, diantaranya teknikdengan menggunakan bola yang meliputi servis, passing bawah, passing atas, smash, dan block. Untuk 
menguasai teknik-teknik dasar tersebut diperlukanlatihan-latihan teknik dasar secara terus menerus dan dilakukan pengulangan daritingkat mudah sampai benar-benar menguasai.Dr. Aep Rohendi, (2018:36) "mengatakan bahwa spike merupakan salah satu tehnik serangan yang sangat efektif selamapermainan”. Dari pendapat ahli tersebut dapat dikatakan bahwa spike sangat berperan penting dalam mencetak angka pada saat pertandingan bola voli, maka dari itu diperlukannya latihan yang baik serta media pendukung latihan yang memadai, maka dari itu media alat latihan smash dan setter bola voli ini sangat berguna untuk membantu mengoptimalkan hasil latihan smash pemain bola voli.

\section{METODE}

Pengembangan alat latihan smash dan setter bola voli ini menggunakan metode penelitian dan pengembangan (reseach and development). Menurut Sugiyono (2013: 407), metode penelitian pengembangan adalah metode penelitian yang digunakan untuk menghasilkan produk tertentu, dan mengkaji keefektifan produk tersebut. Metode penelitian dan pengembangan (research and development) banyak digunakan dalam ilmu alam dan teknik. Namun penelitian dan pengembangan juga bisa digunakan dalam ilmu sosial, manajemen, dan pendidikan. Dalam bidang pendidikan penelitian ini menghasilkan produk. Dalam penelitian ini difikuskan untuk menghasilkan produk alat latihan smash dan setter.

Penelitian ini dilakukan di salah satu club bola voli di semarang yaitu TMP ( Taruna Merah Putih). Penelitian ini melibatkan 20 orang pemain. Sampel yang digunakan dalam penelitian ini adalah sample jenuh karena jumplah populasi relatif sedikit. Menurut Sugiono (2010: 124) "sampling jenuh adalah teknik pengambilan sampel bila semua anggota populasi digunakan sebagai sampel". Pengumpulan data pada penelitian ini berupa validasi, angket dan dokumentasi. Validasi digunakan untuk memvalidasi produk yang dibuat, angket digunakan untuk mengetahui kualitas produk yang di hasilkan. Instrumen wawancara digunakan untuk alat pengumpulan data dari para ahli sehubungan dengan kritik dan saran yang bermanfaat bagi kualitas produk tersebut.

Instrumen penelitian adalah alat atau fasilitas yang digunakan peneliti dalam mengumpulkan data agar pekerjaanya lebih mudah dan hasilnya lebih baik, dalam arti lebih cermat, lengkap dan sistematis sehingga lebih mudah diolah (Suharsimi Arikunto, 2010 :203 ), dalam penelitian ini menggunakan tes dan non tes. Instrumen tes berupa soal dan non tes berupa angket dan dokumentasi. Setelah penyusunan instrumen selesai, peneliti akan mengujicobakan instrumen ke tempat latihan. pengujian ini bertujuan untuk mengetahui validitas dan reabilitas instrumen yang digunakan dalam penelitian. Menurut Sugiyono (2010: 363), validitas merupakan derajat ketepatanantara yang terjadi pada objek penelitian dengan data yang dapat di laporkan oleh peneliti. Sedangkan reabilitas berkenaan dengan drajat konsistensi dan stabilitas data atau temuan. 


\section{HASIL DAN PEMBAHASAN}

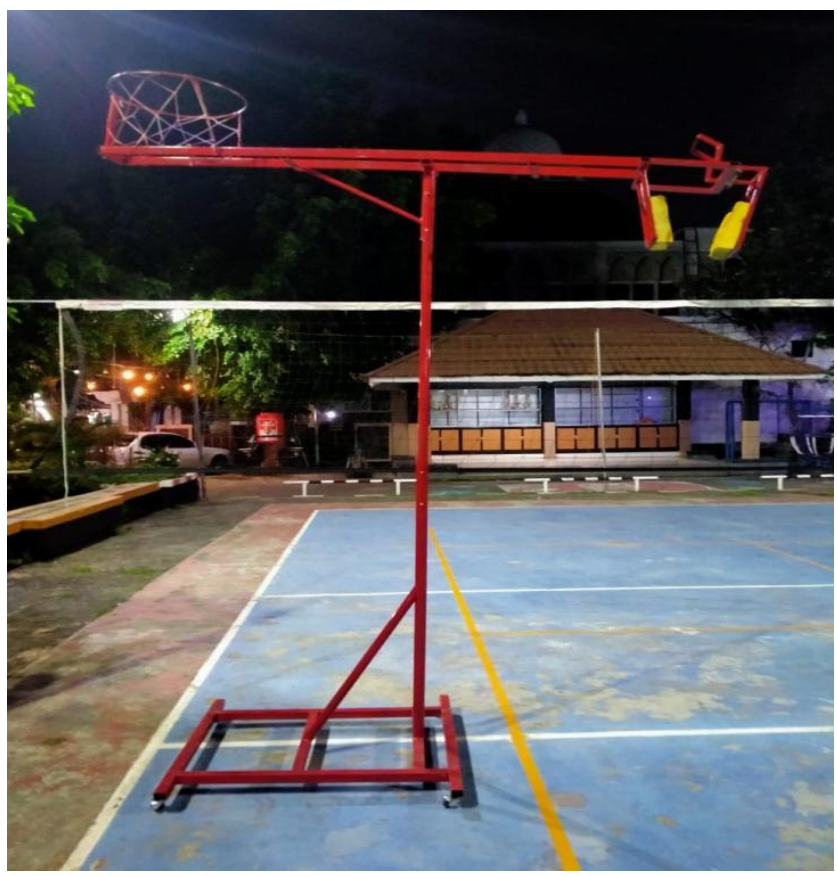

Gambar 1. Hasil akhir alat latihan smash dan setter bola voli.

Hasil dari beberapa penilaian ahli media, pelatih dan responden, menghasilkan alat latihan smash dan setter bola voli yang layak disebut sebagai alat latihan dalam permainan bola voli. Alat ini memiliki berat $18 \mathrm{~kg}$, alat ini juga mudah untuk dipindahkan dari satu tempat ketempat lain, serta pemasangan alat yang mudah karna alat latihan ini sudah didesain sesimpel mungkin atau portabe Pada awal pengembangan alat latihan smash dan setter ini didesain dan diproduksi menjadi sebuah produk awal berupa alat bantu latiahan bola voli untuk proses latihan kedepanya. Proses pengembangan melalui prosedur penelitian dan pengembangan, Melalui beberapa perencanaan, produksi dan evaluasi. Kemudian produk dikembangkan dengan bantuan seseorang yang menguasai teknik pengelasan, setelah produk awal dihasilkan maka perlu dievaluasi kepada para ahli melalui validasi ahli, pelatih dan perlu diuji cobakan kepada pemain. Selanjutnya tahap penelitian dilakukan dengan uji bata awal, uji coba utama dan uji coba operasional.

Proses validasi ahli media menghasilkan data yang digunakan untuk revisi produk awal. Dalam proses validasi ahli media ini peneliti menggunakan dua tahap yaitu tahap I dan tahap II. Data validasi pertama digunakan untuk revisi produk untuk menyempurnakan hingga produk siap digunakan untuk uji coba. Setelah selesai validasi media selanjutnya validasi kepelatih. Dari hasil media didapat data, saran dan masukan untuk memperbaiki kualitas "alat latihan smash dan setter bola voli" yang sedang dikembangkan. Setelah selesai revisi produk hingga siap digunakan untuk uji coba awal, uji coba utama dan uji coba oprasional. 
Kualitas " pengembangan alat latihan smash dan setter" ini termasuk dalam kriteria "layak" pernyataan tersebut dapat dibuktikan dari hasil analisis penilaian "layak" dari kedua ahli baik itu dari ahli media maupun pelatih, serta dalam uji coba awal, uji coba utama dan uji coba oprasional. Pemain merasa senang dan antusias dalam mencoba alat ini karena rasa penasaran dan tertarik ingin mencobanya. Hasil penguji dapat dijabarkan dalam pembahasan berikut.

1. Pengujian kepada ahli media

Hasil uji angket kepada ahli media menunjukan tingkat relevansi kedalam media sebesar $83,8 \%$ yang berarti bahwa materi yang ada dalam penelitian " pengembangan alat latihan smash dan setter bola voli" ini layak digunakan dalam proses latiah.

2. Pengujian kepada pelatih

Hasil uji angket yang dilakukan kepada pelatih menunjukan tingkat kelayakan penelitian sebesar $87,5 \%$ yang berarti penelitian " pengembangan alat latihan smash dan setter bola voli" ini layak digunakan dalam proses latihan.

3. Pengujian kepada responden atau pemain.

a. Uji coba awal

Hasil uji responden mengenai penelitian "pengembangan alat latihan smash dan setter" menurut responden siswa sebesar $82,98 \%$ dikategorikan "layak" yang dapat diartikan bahwa media tersebut layak untuk diujicobakan.

b. Uji coba utama

Hasil uji responden mengenai penelitian "pengembangan alat latihan smash dan setter" menurut responden siswa sebesar $80,72 \%$ dikategorikan "layak" yang dapat diartikan bahwa media tersebut layak untuk diujicobakan.

c. Uji coba operasional

Hasil uji responden mengenai penelitian "pengembangan alat latihan smash dan setter" menurut responden siswa sebesar $84,06 \%$ dikategorikan "layak" yang dapat diartikan bahwa media tersebut layak untuk diujicobakan.

\section{KESIMPULAN}

Hasil dari penalitian " pengembangan alat latihan smash dan setter bola voli” dikategorikan layak digunakan sebagai alat latihan dalam kepelatihan olahraga. Hal ini dapat dilihat dari hasil penelitian ahli media, yaitu $83,8 \%$ dan pelatih $87,5 \%$ serta berdasarkan hasil uji coba lapangan operasional yaitu $84,06 \%$. Berdasarkan hasil penelitian yang telah dinyatakan bahwa pengembangan alat latihan smash dan setter bola voli sudah layak dan tervalidasi oleh ahli media dan pelatih pada bidang olahraga kepelatihan, maka ada beberapa saran sebagai berikut. 
1. Pada pembinaan atlet, pelatih dapat memanfaatkan pengembangan alat latihan smash dan setter bola voli sebagai variasi dalam proses latihan.

2. Atlet dapat memanfaatkan alat latihan smash dan setter untuk berlatih semaksimal mungkin.

3. Praktisi pengembangan alat dapat menguji tingkat keefektifanya dalam latihan dengan melakuhkan peneltian-penelitian terhadap pengembangan alat latihan smash dan setter bola voli dan membuat alat latihan ataupun alat-alat olahraga kepelatihan yang lebih bervariasi.

4. Bagi mahasiwa kependidikan maupun kepelatihan olahraga jangan ragu untuk mengambil judul skripsi tentang penelitian pengembangan. Suatu penelitian pengembangan, layak atau tidak layak tergantung pada bagaimana mengembangkannya dan kepraktisan dalam penggunaannya serta kesediaan alat dan tempat dimana kita menerapkannya.

5. Bagi mahasiswa PJKR UPGRIS ataupun prodi lainya, terutama yang hobbi dalam bidang bola voli diharapkan dapat mengembangkan penelitian pengembangan alat latihan smash dan setter bola voli lebih menarik dan efektif.

\section{DAFTAR PUSTAKA}

Aep R.- Etor S. (2018), Metode Latihan dan Pembelajaran Bola Voli Untuk Umum, Bandung: Alfabeta.

Albab, A.U. Rahayu, T \& Sugiharto, S. (2016). "Pengembangan alat ring bola basket multiguna untuk pembelajaran pendidikan jasmani kesehatan dan rekreasi (penjasorkes) tingkat sekolah dasar kelas $v$ di kota semarang". Journal Of Physical Uducation And Sport. 5(1), 60-66.

Aprianto, T. Firmanto, G. (2017). "Pengembangan alat pelontar bola voli". Prosiding seminar dan lokakarya fakultas ilmu keolahragaan Universitas Negri Jakarta 2 (01), 58-60.

Arikunto, Suharsimi. (2012). Prosedur penelitian: suatu pendekatan praktek. Jakarta: Rinekacipta.

Dewi, R. (2020). “Pengembangan instrumen tes passing bola voli berbasis digital”. Jurnal Prestasi 4 (1), 9-16.

Hadiana, A. (2020) Pengembangan Media Alat Bantu Smash Bola Voli Pada Mahasiswa FIK Universitas Negeri Medan Tahun 2019.UNIMED. digilib.unimed.ac.id/id/eprint/38979

Muttaqin, I. Winarmo, W.E. dan kurniawan, A. (2016). "Pengembangan model latihan smash bola voli pada kegiatan ekstrakurikuler di smp n12 malang". Jurnal Pendidikan Jasmani. 26 (2), 2016.

Nugroho, E. D (2016). “pengembangan alat pelontar bola multifungsi”. Jurnal pend. Kepelatihan olahraga-S1. 1 (2). 
Sugiyono. (2012). Metode penelitian pendidikan : pendekatan kuantitatif, kualitatif, dan R\&D. Bandung : Alfabeta.

Sugiyono. (2015). Metode penelitian dan pengembangan. Bandung: Alfabeta.

Syakur, M.A \& Paramitha, S.T. (2017). "Pengembangan alat bantu latihan pelontar bola futsal berbasis mikrokontroler dengan menggunakan software pemograman arduino". Jurnal Terapan Ilmu Keolahragaan. 2 (1), 29-32. 